\title{
Road barrier effect on small birds removed by vegetated overpass in South East Queensland.
}

\author{
Darryl N. Jones ${ }^{1}$ and Amy R. F. Bond ${ }^{2}$ \\ ${ }^{1,2}$ Applied Road Ecology, Environmental Futures Centre, Griffith University, Nathan, Qld. \\ 4111, Australia. \\ Email: ${ }^{1}$ D.Jones@griffith.edu.au; ${ }^{2}$ A.Bond@griffith.edu.au).
}

\section{Introduction}

The ecological impacts of road networks and traffic have long been recognised although effective approaches to the mitigation of fragmentation influences have generally been minor in scale (Glista et al. 2009). This is changing with a dramatic increase of interest by road authorities, government agencies and consultants in the design of fauna crossing structures. Purpose-built fauna underpasses are now commonly included in plans for new roads and upgrades of existing roads, though relatively few have been adequately surveyed to assess their efficacy (Mata et al. 2008). The largest and most expensive of all wildlife crossing structures are fauna overpasses or land-bridges. Although now abundant in Europe (France alone has over 200 (Corlatti et al. 2009)), four have now been constructed in Australia, with the two most recent being situated within suburban Brisbane.

The Compton Road land-bridge is part of the Compton Road Fauna Structures Array, designed to provide continuity of habitat between major bushland to the north and south of the road, and was completed in 2005 (Fig 1). Monitoring of fauna use of this structure has continued since the end of construction (Veage \& Jones 2008). As with overpasses worldwide, most attention has been on the use of the structure by mammal species, although some studies have included mention of other taxa (Bond and Jones 2008). With few exceptions, birds have not been considered in such studies, presumably because of the assumption that flight enables safe passage over roads, regardless of width and traffic volume (Jacobson 2005). In a small study of two land-bridges in Germany, however, Keller et al. (1996) found that while a number of open country bird species did fly over the road freely, many forest species avoided the road edge. Nonetheless, some of these species were found to cross the road by moving within the vegetation.

Monitoring of the Compton Road land-bridge has demonstrated that the structure is used regularly by three species of macropod and European Brown Hare (Lepus europaeus). The vegetation on the structure, having been planted in 2005 mainly as tube-stock of local provenance, is now a dense, multi-layered habitat with the tallest strata of young trees 
reaching 3.4-4.0 $\mathrm{m}$ in height. The species richness closely resembles that of the surrounding forest, with the addition of about 6 species apparently through natural regeneration.

Although species such as Australian Magpie (Cracticus tibicen), Pied Butcherbird (Cracticus nigrogularis) and Torresian Crow (Corvus orru) were noted using the structure soon after construction, it was the unexpected sightings of several small forest bird species within the rapidly growing vegetation which prompted the first systematic surveys of bird presence on the land-bridge. In 2008 we undertook observations on parts of the road with and without a land bridge to identify whether there is a road barrier effect and whether this is ameliorated by the land-bridge.

\section{Undertaking the bird surveys}

. To compare movements of birds crossing the road with those using the land-bridge, we undertook 5-minute stationary observations at eight transects: four spanning the road (10m wide and $65 \mathrm{~m}$ long, placed perpendicular to the road $100 \mathrm{~m}$ and $200 \mathrm{~m}$ eat and west of the land-bridge and four on the structure (10m wide, $15-30 \mathrm{~m}$ long, placed parallel to the road). All surveys were undertaken between dawn and 08.00 hours on fine days with all eight completed in random order each session. All birds detected flying from one side of the road to the other were counted and identified; birds flying above the level of the surrounding vegetation were ignored. Road transects were observed from fixed points on either side of the road, two directed to the west and two directed to the east. The four land-bridge transects were sited at locations equally spaced over the structure and spanning its full width. Here we report on the first phase of this study, comprising 24 survey days conducted between March and October 2008.

\section{What we found}

A mean of 6.25 birds per 5-minute period was detected crossing the road away from the landbridge. A total of 150 individuals of 14 species were identified flying over the road (Table 1), with Torresian Crow and Rainbow Lorikeet (Trichoglossus haematodus) being the most abundant, making up $43.3 \%$ and $28.0 \%$ of the total respectively. On the land-bridge, a mean of 6.71 birds per survey was detected and this mean was not significantly different to that of birds flying over the road $(\mathrm{t}=0.004$, d.f. $=23$, NS). A total of 161 individuals were recorded crossing the land-bridge with the most common species being Red-browed Finch (Neochmia temporalis) (15.4\%), Silvereye (Zosterops lateralis) (10.6\%) and White-throated Honeyeater (Melithreptus albogularis)(9.2\%). A comparison of the number of passerines (typical bush birds, but excluding crows) and non-passerines flying over the road versus flying over the land-bridge was highly significant $\left(X^{2}=137.6, \mathrm{df}=1, \mathrm{p}<0.0001\right)$, indicating almost complete segregation of the two groups. In all, a total of 23 species was detected using the land-bridge, 
with 17 (74.9\%) of these being found only on the structure and not detected crossing the road away from the land-bridge (Table 1).

The modal weight of birds flying over the road (115g) was also considerably heavier than that of species crossing the road using the land-bridge (15g). Furthermore, while the land-bridge species were typical bushland species such as honeyeaters and Silvereye, the list also included species normally regarded as being sensitive to disturbance and often found far from edges. For example, the Rose Robin (Petroica rosea) and White-throated Treecreeper (Cormobates leucophaea) were detected within the land-bridge vegetation.

\section{Implications}

These early findings are important for two reasons. First, they draw attention to the likelihood that many species of birds, primarily smaller forest-associated species, may be impacted significantly by the presence of roads, despite their ability to fly. While many urban-tolerant species obviously do try to cross across even wide busy roads, many apparently do not. Second, for at least some such species the apparent barrier effect of the road appears to be mitigated by the presence of a well-vegetated fauna overpass. Clearly, this is an area of applied research that requires far more international attention.

\section{Acknowledgements}

We are extremely grateful to the volunteers who assisted in these bird surveys, including Matthew Bakker, Orphe Bichet, James Bunker, Gluzar Manzar, Ian Mitchell, Jonathan Pickvance, Robert Povey, Martin Studer and Tracey Wearing.

\section{References}

Bond, A. R. F and Jones, D. N. (2008). Temporal use of fauna underpasses and overpasses. Wildlife Research 35, 103-112.

Corlatti, L., Hackländer, K. and Frey-Roos, F. (2009) Ability of wildlife overpasses to provide connectivity and prevent isolation. Conservation Biology 23, 548-556.

Glista, D. J., DeVault, T. L. and DeWoody, J. A. (2009). A review of mitigation measures for reducing wildlife mortality on roadways. Landscape and Urban Planning 91: 1-7.

Jacobson, S.L. (2005) Mitigation measures for highway-caused impacts to birds. USDA Forest Service Technical Report PSW-GTR-191, 1048-1050.

Keller, V., Bauer, H. Ley, H. and Pfister, H. (1996) Bedeutung von Grünbrücken über Autobahnen für Vögel. Der Orithologische Beobachter 93, 249-258.

Mata, C., Hervás, I., Herranz, J., Suáraz, F., and Malo, J. (2008) Are motorway wildlife passages worth building? Vertebrate use of road-crossing structures on a Spanish motorway. J. Environmental Management 88, 407-415. 
Veage, L. and Jones, D.N. (2008) Breaking the Barriers: Assessing the Value of Fauna-Friendly Crossing Structures at Compton Road. Report to Brisbane City Council, Centre for Innovative Conservation Strategies, Pp. 112. 
Table 1. Total number of individuals detected on bird species crossing Compton Road or on the land-bridge during 24 surveys March-October 2008.

\begin{tabular}{lcc}
\hline Common name & Road & Land-bridge \\
\hline Torresian Crow & 65 & 11 \\
Rainbow Lorikeet & 42 & 1 \\
Pale-headed Rosella & 14 & \\
Welcome Swallow & 6 & \\
Galah & 4 & 5 \\
Scaly-breasted Lorikeet & 4 & \\
Australian Magpie & 3 & 4 \\
Sulphur-crested Cockatoo & 3 & 2 \\
Noisy Friarbird & 3 & \\
Black-faced Cuckoo-shrike & 2 & 3 \\
Pacific Black Duck & 1 & \\
Channel-billed Cuckoo & 1 & 25 \\
Grey Butcherbird & 1 & 17 \\
Olive-backed Oriole & 1 & 15 \\
Red-browed Finch & & 14 \\
Silvereye & & 14 \\
White-throated Honeyeater & & 13 \\
Grey Fantail & & 8 \\
Red-backed Fairy-wren & & 8 \\
Yellow-faced Honeyeater & & 8 \\
Brown Honeyeater & & 3 \\
Striated Pardalote & $\mathbf{1 4}$ & 3 \\
Eastern Yellow Robin & & 23 \\
Thornbill & & 1 \\
Crested Pigeon & & 1 \\
Grey Shrike-thrush & & 1 \\
White-throated Treecreeper & & \\
Variegated Fairy-wren & & \\
Rose Robin & & \\
Willy Wagtail & & \\
Figbird & & \\
No. of individuals & & \\
No. of species & & \\
Mean per survey & & \\
\hline
\end{tabular}

